\title{
Central American
}

National Cancer Institute

\section{Source}

National Cancer Institute. Central American. NCI Thesaurus. Code C67118.

Denotes a person from the area between north and south America including persons from Belize, Costa Rica, El Salvador, Guatemala, Honduras, Nicaragua, Panama, and the Panama Canal zone. 